\title{
LAND, DEATH AND DOWER IN THE SETTLER EMPIRE: THE LOST CAUSE OF "THE WIDOW'S THIRD" IN NINETEENTH-CENTURY NEW ZEALAND
}

\author{
Charlotte Macdonald*
}

\begin{abstract}
Exploration of dower right or the 'widow's third' in 1840s-70s New Zealand provides an additional perspective on marriage and property history to the better known story of late 19thC married women's property reform. New Zealand practice broadly followed the curtailed dower history of the 1833 Dower Act (England) with further acceleration driven by the desire to rapidly disencumber land title in order to free property in land for easy sale and exchange. Several dower cases are traced, revealing the circumstances of widows in the social and economic fabric of colonial communities. Debates in the settler parliament in the 1870s reveal increasingly divergent set of understandings around land as property, about inheritance and a concern for the situation of women within, but not beyond, marriage.
\end{abstract}

Among the cases identified in the New Zealand Lost Cases project are a small number involving claims to dower. Dower, or "the widow's third" was the ancient common law entitlement of a widow to a life-interest in a third of the real property owned by her husband following his death. Unlikely contenders for the sobriquet as "leading cases", the dower cases of Sutton v Howells, $1865,{ }^{1}$ Gray v

* Professor of History, Victoria University of Wellington. Grateful thanks to Judith McKoy for research assistance; Shaunnagh Dorsett and Megan Simpson for edification on points of law and for materials from the Lost Cases project; Felicity Rashbrooke, Parliamentary Library, for reference help; Bettina Bradbury for generously allowing me to read excerpts of her Wife to Widow: lives, laws and politics in 19th Century Montreal (UBC Press, Vancouver, forthcoming) prior to publication, and to the Faculty of Humanities and Social Sciences Research Committee, Victoria University of Wellington, for financial support.

1 Re Sutton v Howells Supreme Court Napier, 5 August 1865 per Johnston J, reported in Hawke's Bay Herald (Napier, 12 August 1865) at 2. 
Beverley, $1866,{ }^{2}$ and Clarke \& wife v Laurie, $1874,{ }^{3}$ reveal the operation of a little known but illuminating aspect of the law in colonial New Zealand while also proving the value of the legal record as a point of access for social history. The case materials generated by courts provide a rich insight into the interstices of everyday social and economic life, a perspective rarely available from personal papers or even other aspects of the public record. ${ }^{4}$ Local courts and newspapers were mutually supporting, the public platforms of law and print proving popular in even the most remote colonial communities.

Dower also has particular things to tell us. While the modern trajectory of dower law is one of curtailment, especially following the English 1833 Dower Act codifying the limitations on widows' entitlements, ${ }^{5}$ the history of dower in nineteenth-century British colonies, and across the common law world more generally, is curiously divergent. In some places, notably Canada, the law of dower was refashioned, elaborated and given new life through a convergence of agrarian and liberal ideals. ${ }^{6}$ Elsewhere, as in New South Wales and New Zealand, dower was speedily despatched as an encumbrance on easy transactions in land. ${ }^{7}$ Linking marriage, land and law, and dower presented

2 Gray v Beverley SC Dunedin, 5 January 1866 per Chapman and Richmond JJ, reported in Otago Daily Times (Dunedin, 4 January 1866) at 5; (27 February 1866) at 5; (1 March 1866) at 4.

3 Clarke \& wife v Laurie, SC Auckland, 11 December 1874 per Gillies J, reported in Daily Southern Cross (Auckland, 22 July 1875), at 1; Supreme Court Civil Minute Book 1870-1875, Archives New Zealand (ANZ), Auckland, BBAE 5635 6a, at 332-333.

4 Frances Porter and Charlotte Macdonald My Hand Will Write What My Heart Dictates: the unsettled lives of women in nineteenth-century New Zealand as revealed to sisters, family and friends (Bridget Williams Books/Auckland University Press, Wellington and Auckland, 1996) [My Hand Will Write]; Charlotte Macdonald (ed) Women Writing Home. New Zealand (Pickering \& Chatto, London, 2006) vol 5; Diana Meads, Philip Rainer and Kay Sanderson Women's Words: a guide to manuscripts and archives in the Alexander Turnbull Library relating to women in the nineteenth century (Alexander Turnbull Library, Wellington, 1988); Caroline Daley (ed) Women and Empire 1750-1939: New Zealand (Routledge, London, 2009), vol 2; Katie Pickles "Colonisation, Empire and Gender" in Giselle Byrnes (ed) The New Oxford History of New Zealand (Oxford University Press, Melbourne, 2009) 219.

5 An Act for the Amendment of the Law relating to Dower 18333 \& 4 Wm IV c 105.

6 Philip Girard "Land Law, Liberalism, and the Agrarian Ideal: British North America, 1750-1920" in John McLaren, AR Buck and Nancy E Wright (eds) Despotic Dominion. Property Rights in British Settler Societies (UBC Press, Vancouver, 2005) 120; Catherine Cavanaugh "The Limitations of the Pioneering Partnership: the Alberta Campiagn for Homestead Dower, 1909-25" (1993) 74 Canadian Historical Review 198.

7 Nancy E Wright "The Lady Vanishes: Women and Property Rights in Nineteenth-Century New South Wales" in McLaren Despotic Dominion, ibid, 190; Hilary Golder and Diane Kirkby "Land, Conveyancing Reform and the Problem of the Married Woman in Colonial Australia" in Cathy Coleborne and Diane Kirkby (eds) Law, History, Colonialism. The Reach of Empire (Manchester University Press, Manchester, 2001) 207 ["Land, Conveyancing Reform"]; AR Buck and Nancy E Wright "The Law of Dower in New South Wales and the United States. A Study in Comparative Legal History" in Hamar Foster, Benjamin L Berger and AR Buck (eds) The Grand Experiment. Law and Legal Culture in British Settler Societies (UBC Press, Vancouver, 2008) 208 ["The Law of Dower"]. 
problems to a nineteenth-century world in which understandings of all three were in great flux. It lay close to the heart of the reshaping of property rights, political and gender identities which form the central dynamics of a nineteenth century characterised by high degrees of mobility of people, ideas and legal practice. Such reshaping went on in the daily business of dealing with death, land and marriage, and at the level of public debate in newspapers and legislatures. A common strand across the British world, it is also a powerful indicator of the varying histories encompassed in the wider imperial project. In its core concern with land as a property right it was also a part of settler colonies' appropriation of land from their indigenous inhabitants and redistribution to incoming, largely European, populations. ${ }^{8}$

Dower law has attracted little scholarly attention to date in New Zealand. As a footnote in legal textbooks it features as an historic, almost archaic relic. ${ }^{9}$ Rosalind Atherton suggested in 1990 that "the law as to dower had little application". ${ }^{10}$ The development of family protection law, married women's property law, and women's political rights, by comparison, have gained greater recognition and have been accorded a key role in the overall emergence of a distinctive legal and national culture. ${ }^{11}$ Married women's property protection Acts were passed in 1860, 1870 and $1884 ;{ }^{12}$ New Zealand women were the first in a nation state to gain the vote in 1893, while the Testators' Family Maintenance Act of 1900 has been regarded as a bold innovation. ${ }^{13}$ But this "progressive" story of an acquisition of rights later in the century was preceded by the loss of dower right. Both were responses to women's legal disabilities within marriage, and in particular, to the situation of coverture in which women lost almost all legal identity as married women, including powers to own, control or dispose of property. While Bradbury has outlined how these disabilities were gradually dismantled during the later decades of the nineteenth cenury, in New Zealand as

8 The installation of "an influential doctrine of individual property rights in land", as John Weaver terms it, was crucial to the success of settler colonies: John Weaver The Great Land Rush and the Making of the Modern World, 1650-1900 (McGill-Queen's University Press, Montreal and Kingston, 2003).

9 EC Adams (ed) Garrow's Law of Real Property in New Zealand (5th ed, Butterworths, Wellington, 1961) at 141 assures us that: "The law student may now regard dower as a ghost of the past".

10 Rosalind Atherton "New Zealand's Testator's Family Maintenance Act of 1900 - the Stouts, the Women's Movement and Political Compromise" (1990) 7 Otago L R 202

11 Atherton "New Zealand's Testator's Family Maintenance Act", ibid; Bettina Bradbury "From Civil Death to Separate Property: Changes in the Legal Rights of Married Women in Nineteenth-century New Zealand" (1995) 29 New Zealand Journal of History 40 ["From Civil Death"]; Patricia Grimshaw Women's Suffrage in New Zealand (rev ed, Auckland University Press, Auckland, 1987); Michael King Penguin History of New Zealand (Penguin Books, Auckland, 2003); Philippa Mein Smith Concise History of New Zealand (Cambridge University Press, Melbourne, 2005).

12 Married Women's Property Protection Act 186024 Vic No 9; Married Women's Property Protection Act 187033 \& 34 Vic No 37; Married Women's Property Act 188448 Vic No 10.

13 Family Maintenance Act 1900 
elsewhere, she has also pointed to the complexity of this history across the British colonial world. ${ }^{14}$ The abolition (or desire for abolition) of dower rights, she suggests, was part of the emergence of a liberalism that gave primacy to individual property rights of men and easy exchange. In this context dower was not just a private and domestic question but a critical political and economic issue of the time: "Patriarchy, capitalism and liberal rights were interwoven public issues", ${ }^{15}$ Dower was a powerful symbol of different legal and political cultures emerging in the imperial world, between "old" and "new" societies but also where there were competing jurisdictions as in Upper and Lower Canada. ${ }^{16}$ The "problem of the married woman" in relation to land and marriage law has also been considered by Golder and Kirkby, Buck and Wright, writing of the Australian colonial scene. ${ }^{17}$ Settler colonialism depended on marriage and land acquisition, especially in the kind of orderly colonisation which was central to New Zealand's development from 1840. But both marriage and land ownership required continual re-making in the colony, as they did across the imperial world. ${ }^{18}$ As early as 1842, for example, an ordinance passed in New Zealand allowed conveyancing between husband and wife, a practice not possible in England at this time. ${ }^{19}$

In what must be regarded as a very preliminary exploration of the subject, and one leaning more towards what Jim Phillips has referred to as a study in "low law", 20 the discussion below is in three broad sections. The first two consider circumstances where a dower right was invoked in colonial

14 Bradbury "From Civil Death", above n 11; Bettina Bradbury "Colonial Comparisons: Rethinking Marriage, Civilisation and Nation in 19th-century White Settler Societies" in Philip Buckner and R. Douglas Francis (eds) Rediscovering the British World (University of Calgary Press, Calgary, 2005) 135; Bettina Bradbury Wife to Widow: lives, laws and politics in nineteenth-century Montreal (UBC Press, Vancouver, forthcoming) [Wife to Widow].

15 Bradbury Wife to Widow, ibid.

16 Ibid.

17 Golder and Kirkby "Land, Conveyancing Reform" above n 7; Buck and Wright "The Law of Dower" above n 7; Nancy E Wright, "Local Policy and Legal Decisions about Dower in Colonial New South Wales" (2005) ANZLH E-Journal 226; AR Buck "A Blot on the Certificate: Dower and Women's Property Rights in Colonial New South Wales" (1987) Australian Journal of Law and Society 87.

18 Sarah Carter The Importance of Being Monogamous: Marriage and Nation Building in Western Canada to 1919 (AU Press and University of Alberta Press, Edmonton, 2008); Angela Wanhalla In/visible sight: The Mixed-descent Families of Southern New Zealand (Bridget Williams Books, Wellington, 2009) [In/visible sight]; Charlotte Macdonald "To Have and To Hold: marrying, promising, exchanging" (paper presented at Interracial Intimacy: New Zealand Histories Symposium, University of Otago, Dunedin, 18-20 June 2009); Philippa Levine (ed) Gender and Empire (Oxford University Press, Oxford, 2004); Adele Perry On the Edge of Empire: Race, Gender and the Making of British Columbia 1849-1871 (University of Toronto Press, Toronto, 2001).

19 An Ordinance to Facilitate the Transfer of Real Property 18425 Vic No 10, s 38; Bradbury "From Civil Death", above n 11, at 42 .

20 Phillips in this volume. 
New Zealand - the cases involving Susan and William Howells, John and Hannah McLean (later Hannah Gray) and, very briefly, also Clarke and Laurie. The third section turns to legislative interest in addressing the problem of dower in the settler parliament from the early 1850 s to the late 1870 s.

\section{WILLIAM AND SUSAN HOWELLS, SUTTON V HOWELLS, $1865^{21}$}

William and Susan Howells were well known in central Hawke's Bay in the early 1860s. They were proprietors and licensees of the Travellers Rest Hotel on the north bank of the Waipawa River. ${ }^{22}$ At a key junction, it was a convenient stopping-off point for people travelling north-south between Wellington and the Hawke's Bay, or east-west along the Waipawa river valley where state highway two now meets the inland route via Ongaonga. The Howells were also landowners in the rapidly growing east coast pastoral district; they were among those making a success of the opportunities made possible for settlers by land purchases from Maori, investment of capital and in early securing of strategic businesses. ${ }^{23}$ They were in their early 30 s, married, but without children. In the small and scattered settlements throughout such districts the annual horse race meeting was a major social and sporting event. Local "race days", often 2-day meetings held over Friday and Saturday, were high points in the community's summer calendar. ${ }^{24}$ William Howells was better known than many attending the meetings in the early 1860s. As one of the organisers of the Waipukurau races, he was one of those with whom entrants for the summer horse races were invited to register. ${ }^{25}$ In late 1863 something seriously bad stopped William Howells' otherwise successful path in its tracks. He did not live to preside over the starting gate at the 1864 race meeting, or over the bar of his hotel. On the evening of Wednesday 25 November 1863 William Howells' dead body lay in the hotel where he had so recently been host and proprietor.

21 Contemporary sources refer both to "Howell" and "Howells". The latter has been adopted here for consistency.

22 Waipawa would later become one of the classic "court towns" in the era in which sittings of the Native Land Court occupied major space in many North Island districts: oral comment by Richard Boast (Leading Cases Conference, Victoria University of Wellington, Wellington, June 2010).

23 Jim McAloon No Idle Rich: The Wealthy in Canterbury and Otago 1840-1914 (Univerity of Otago Press, Dunedin, 2002); Jim McAloon "The New Zealand Economy 1792-1914" in Byrnes The New Oxford History, above n 4, 197; WJ Gardner, "A Colonial Economy" in WH Oliver with BR Williams (ed) Oxford History of New Zealand (Clarendon Press; Oxford and Wellington, 1981) 57; MDN Campbell "The Evolution of Hawke's Bay Landed Society, 1850-1914" (PhD thesis, Victoria University of Wellington, 1972).

24 Charlotte Macdonald "Ways of belonging - Sporting Spaces in New Zealand History" in Byrnes The New Oxford History, above n 4, 269; Carolyn J Mincham "Horseracing in the New Zealand Colonial Community" (MA thesis, Massey University, 2001). Alison Clarke Holiday Seasons: Christmas, New Year and Easter in nineteenth-century New Zealand (Auckland University Press, Auckland, 2007).

25 Hawke's Bay Herald (Napier, 16 February 1861) Supplement at 1. 
The law came to life as William went to his grave. An inquest; adminstration of his estate, including Susan's claim to dower; and, very many years later, a precedent-setting case in the English Court of Chancery, all meant William Howells tragically short life cast a long legal shadow.

Earlier in the day on which he died, William Howells had gone to nearby Kaikora, northwest of Waipawa, with friends William Hayes and Henry Hollier. They had spent some time in the local pub where William had three glasses of brandy and syrup. The group were back at Waipawa, and Howells at his own house later that day. By 8 o'clock that evening, however, Howells was in a high state of agitation, raging through the hotel, shouting, threatening first with an axe, before breaking down a bedroom door and ordering servant Sarah Alexander to bring him a gun. He threatened to kill himself and, from one witness, to take the life of his wife as well. Before anyone was aware he took up a glass tumbler from the bar, filled it with strychnine and swallowed the contents. Susan Howells, discovering what William had done, cried out for help. Dr Venn, the local surgeon, came at speed. He made several attempts to administer an emetic in the form of a mustard solution but Howells resisted, at one stage telling Venn: "I shall take nothing from you". ${ }^{26}$ Howells slipped into a state of vomiting and convulsive fits. He died within an hour or so.

Nine witnesses appeared before the inquest convened the next day by Charles English, the local coroner. They included Dr Venn, Charles Robson, "an analytical chemist", Howells' two buddies of the previous day's excursion to Kaikora (Hayes and Hollier), Sullivan the hostler, Sarah Alexander the housemaid, and a man named Brears (who had also been at the Kaikora pub). Having heard the evidence, the jury of twelve "good and lawful men of the district" (including storekeeper Edward Bibby), ${ }^{27}$ had no difficulty in returning a verdict: "that the said William Howells, died on the 25th day of November, 1863, at Waipawa, from the effects of strychnine, administered by his own hand, with intent to destroy his life." The verdict was felo de se (a felon of himself, self murder). ${ }^{28}$ Susan Howells was not called as a witness. ${ }^{29}$ While drownings and deaths by accident were more common

26 Coroner's inquest file William Howells (ANZ) Wellington, J1, 1863/1317.

27 A photograph of "good and lawful" juror Edward Bibby's General Store at Waipawa, taken in 1862, can be found at Alexander Turnbull Library (ATL), Wellington, PA-Coll-2838-2-05.

28 Hawke's Bay Herald (Napier, 5 December 1863) at 2.

29 Coroner's inquest file William Howells, above n 26; Death certificate William Howells, Register of Births, Deaths and Marriages, Department of Internal Affairs, registration number 1863002079. The death certificate gives date of death as 24 November but the inquest is clear in noting 25 November as date of death. John Weaver (McMaster University) is of the view that rules of evidence and procedures in Coroners Inquests were much more relaxed than in criminal and other courts and it would be normal for husbands and wives to give evidence in such instances (personal communication). So it is odd that Susan Howells was not a witness. Hannah Maclean was in the death of her husband John. 
at the time, Howells' unfortunate end shared a factor present in many sudden deaths in this period: alcohol. ${ }^{30}$

The witness statements give little indication of the circumstances which led William Howells to the extremities of that Wednesday. Was it simply that he had entered a rage and insensibility by drinking a great deal? Everyone who had spent time with him that day had seen him drinking, but none had seen him drunk. There is some evidence of angry words directed to his wife Susan. Was this just the drink talking or was there the substance of an argument? None was mentioned, nor was there any evidence given as to other difficulties in which Howells was embroiled. The inquest file sheds light on the comings and goings of Howells, Hayes and Hollier on an early summer day in which three pubs could be visited within an easy half day's ride, and on the various everyday pursuits in which residents of the town were engaged when called to the emergency.

Susan Howells found herself, on 26 November 1863, a widow. Her state of mind through the shock of the events, the inquest and the discreet burial of a suicide for whom the usual consolations of Christian burial were not available, have left no record. We do know she sought, very soon after, to continue as proprietor of the Travellers Rest. The annual renewal of publicans' licenses for the district were due to be heard on 10 December by the local Licensing Board (a gathering of local JPs). She applied for renewal of the license in her own name. Her's was the only application rejected, no reasons were given as to why. ${ }^{31}$ Women, widows or not, held licenses in other parts of the country so it can only be surmised that the Board had grounds for considering Susan unsuitable. $^{32}$

William Howells may have acted deliberately in taking his own life, but he did not make provision for his death by making a will. He died intestate, despite being "possessed of real estate ... of considerable value" at the time of his death. ${ }^{33}$ The administration of his estate became the

30 David Madle "Patterns of Death by Accident, Suicide and Homicide in New Zealand 1860-1960, Interpretation and Comparisons" (PhD dissertation, Victoria University of Wellington, 1996); John Weaver and David Wright (eds) Histories of Suicide: international perspectives on self-destruction in the modern world (University of Toronto Press, Toronto, 2009); John C Weaver A Sadly Troubled History: the meanings of suicide in the modern age (McGill-Queen's University Press, Montreal, 2009). Greg Ryan "Drink and the historians: sober refletions on alcohol in New Zealand 1840-1914" (2010) 44 New Zealand Journal of History 35; Paul Christoffel "Removing Temptation: New Zealand's Alcohol Restrictions, 1881 2005" (PhD dissertation, Victoria University of Wellington, 2006); Miles Fairburn The Ideal Society and its Enemies. The Foundations of Modern New Zealand Society 1850-1900 (Auckland University Press, Auckland, 1989) [The Ideal Society].

31 Hawke's Bay Herald (Napier, 19 December 1863) at 3. The licensing authority was made up of GS Cooper, Resident Magistrate and three local men: "esquires", JPs. The Meeting was held on 10 December 1863.

32 Letter from Greg Ryan personal communication (1 June 2010); Sandra Quick "The Colonial Helpmeet Takes a Dram: Women Participants in the Central Otago Goldfields Liquor Industry 1861-1901" (MA dissertation, University of Otago, 1997).

33 Rees v de Bernady (1896) $2 \mathrm{Ch} 437(\mathrm{Ch})$ at 437 per Romer J. 
responsibility of the Supreme Court. From 1844 to 1865 intestate estates were a responsibility of the Registrars of the Supreme Court, and from 1865, the responsibility of special Curators of Intestate Estates. The Public Trust Office opened for business in 1873. ${ }^{34}$

Early in the new year, 1864, the Supreme Court appointed Napier businessman and "gentleman" Vautier Janisch as Receiver of real estate in the Howells estate. ${ }^{35}$ At the same sitting "special application" was made on behalf of Frederick Sutton, a Napier merchant, in a suit against William Howells. While details are lacking, it can be speculated that Sutton, a local merchant, was seeking to recover money owed to him by the estate. The main asset was likely the Traveller's Rest. The property and business was duly put up for lease and the new licensee, John Brodie opened for business early the following month, in March 1864. At the newly named Abbotsford Hotel travellers were promised "a good half-way house, with comfortable and well-built Bed Rooms and Sitting Rooms, and every convenience for the comfort of Ladies and Gentlemen. Great attention ... paid to the stabling accommodation, and every care taken of Horses". ${ }^{36}$

Both Susan Howells and Frederick Sutton had to wait longer for William Howells' estate to be sorted, and thereby, to advance their interests under the law. Only in August 1865 did the Court hear an application for widow's dower to be paid from the estate to Susan Howells. The Receiver was duly ordered to pay a third of the rents received on William Howells' properties since his death to her, and to continue to do so on a half-yearly basis. ${ }^{37}$ The cursory newspaper reportage suggests the matter was dealt with routinely and that the judgement was an uncontroversial one (but of sufficient public interest to feature in the newspaper column). Sometime in the following year Susan Howells remarried, her new husband being one James Bennett. The last sight of Susan in the historical record comes from November of 1867 when she successfully applied to have a new receiver appointed. Janisch, whose business failed in 1867 and subsequently left the province, was replaced by Edward Lyndon. ${ }^{38}$ Lyndon was to retain trusteeship for the next 20 years in which the Howells estate remained an unclaimed estate under direction of the Court, until finally passing to the Public Trustee in $1883 .{ }^{39}$

34 CW Vennell A History of the New Zealand Public Trust Office 1873-1973 (Wilson and Horton, Auckland, 1973) at 21.

35 Supreme Court Minute Book, 10 February 1864, ANZ, Wellington, AAOW W3244 291 at 64; Hawke's Bay Herald (Napier, 13 Feb 1864) at 2.

36 Hawke's Bay Herald (Napier, 27 February 1864), at 2.

37 Supreme Court Minute Book, 5 August 1865, ANZ, Wellington, AAOW W3244 29 1, at 107; Hawke's Bay Herald (Napier, 12 August 1865) at 2: "one third of the rent received since the death of Howells, to his widow, and, for the future, the same half-yearly".

38 Hawke's Bay Herald (Napier, 19 Sep 1868); (20 March 1869) at 2; (20 July 1900) at 2.

39 See notice of sale of properties from Howells estate advertised for sale by Lyndon "under direction of the public trustee": Hawke's Bay Herald (Napier, 10 March 1885) at 2. 
The significance of the case, in the first instance, is that it demonstrates dower "at work" in New Zealand. Susan's claim to a third of the income from the properties was acknowledged as an undisputed and primary call on the estate. Her widow's right existed before and beyond any claims by creditors, and before any final settlement or distribution of the estate was completed. The Court was acting within the terms of dower right as in existence through common law, as set out in the imperial Act, the 1833 Dower Act, and the New Zealand Dower Act of $1854 .{ }^{40}$ There is nothing to suggest that William Howells' suicide in any way influenced the Court in judging her entitlement to dower.

Susan Howells (Bennett) and the Howells estate disappear from the record for almost 25 years. ${ }^{41}$ In the 1890 s they came spectacularly back into view through a series of events which echo the great themes of Victorian popular fiction - a lost inheritance, colonial wealth (brushed with moral ambiguity and male), simple rural virtue (female) and a double-dealing businessman with a taint of foreign blood. Through the work of next-of-kin agents, London-based De Bernardy Brothers, descendants of William Howells' estate were located living in rural England in 1889. Margaret Walters and Jane Yorke, cousins of William Howells, were "widows ... over seventy years of age ... uneducated, illiterate, and living in very humble circumstances". ${ }^{42}$ De Bernardy Brothers made their living by tracing long lost connections, especially those in which there was a substantial and unclaimed estate. ${ }^{43}$ It was an opportune business to be in by the late nineteenth century, given the many families which had lost touch over distance and generation as a result of the large scale diaspora of British and European people to the "new worlds" of the Americas and settler colonies such as New Zealand and Australia. ${ }^{44}$ De Bernardy Brothers, it appears, became aware of the Howells estate once it passed into the hands of the Public Trustee in 1883. Their first investigation led them to Reverend R. Weston, a Howells descendant on the maternal side. Offering Weston a deal whereby he would receive two-thirds of the estate and the company one-third, Lucien De Bernardy drew up an agreement to disclose the information he held and pursue the necessary legal processes. De Bernardy Brothers duly instructed solicitors in New Zealand to draw up documents and the title of Reverend Weston was established to the satisfaction of the Supreme

40 Dower Act 185418 Vic No 3

41 Nothing further is known of Susan Howells (Bennett). Searches under both marriage and death indexes for Susan Howells (Bennett) do not reveal her fate. While a Susan Howell does appear in probate files for 1900 there is no evidence to suggest this is the same person.

42 Rees $v$ de Bernardy, above n 33, at 438 per Romer J.

43 Another meaning for "lost cases" might be found in the work of such agents.

44 Messrs de Bernady (often also spelt Bernardy) published a "Next of Kin Gazette" with names or hints of details of unclaimed monies, inviting descendants to contact their offices. See for example Hawke's Bay Herald (Napier, 13 May 1878) at 2; Timaru Herald (Timaru, 13 December 1876) at 5; Thames Star (Thames, 18 December 1878) at 2; Otago Witness (Dunedin, January 1894) at 26; Bruce Herald (Milton, 25 December 1883) at 3. 
Court of New Zealand. At this stage the inquest file from 1863, which had been languishing in the office of Wilson and Cottrell in Napier, was returned to the Department of Justice in Wellington with an apologetic note (Wilson had been Susan Howells' solicitor in her claim to dower in 1865). Pencil annotations on the file indicate a failed attempt in the 1880 s to locate original witnesses to the inquest held twenty years earlier. ${ }^{45}$

Before these arrangements were complete, however, the existence of Jane Yorke and Margaret Walters as closer relatives and thus prior claimants came to light. De Bernardy saw a better opportunity in these two elderly, naïve (to their view), and poorly circumstanced women, proceeding to secure an undertaking of secrecy from Reverend Weston while offering their services to the two women in claiming the Howells estate on the basis that the women would receive half and De Bernardy's the other half share. Jane Yorke and Margaret Walters signed the necessary legal documents, and duly received the first portion of their new wealth, a sum of 1800 pounds. Unfortunately, they had little time to enjoy it. Before full payment was made, both women died (in July and November 1893 respectively).

Their executors, Jane Rees, William and Joseph York, discovered de Bernardy's double-dealing. Considering their actions to have been unfair, they took action in Chancery. Rees $v$ de Bernardy was heard in 1895 before Romer $\mathrm{J}^{46}$ At issue were questions of champerty and maintenance ("a proceeding in which a person having no legitimate concern in a suit bargains to aid in or carry on its prosecution or defense in consideration of his receiving, in the event of success, a share of the matter in suit. Champertous contracts were formerly always illegal"47). The executors believed Lucien de Bernardy had taken advantage of the weak position of Howells' beneficiaries and had unjustly, immorally and illegally enriched himself at their expense. ${ }^{48}$ The court agreed, finding in the plaintiffs' favour and ordering costs against the defendant and a reconsideration of the payments made from the estate. The sums at issue were substantial; the estate as a whole was estimated to be worth around $£ 6,000$. The ruling was reported at length and came to serve as a longstanding precedent. Rees $v$ de Bernardy became the leading case in heir locator agreements in England and Ireland. The recent rigid application of the principles established by Rees $v$ de Bernardy by the Irish Supreme Court in a 1996 case involving a deceased estate in the US state of New Jersey, a London

45 Wilson Cotterill [or Wilson \& Cotterill] to Undersecretary, Department of Justice (25 August 1888), in Coroner's inquest file William Howells, above n 26.

46 Rees $v$ de Bernardy, above n 33.

47 Webster's Collegiate Dictionary (3rd Merriam ed, Springfield (Mass), 1922) at 168.

48 Champerty is still a legal doctrine. It is a subset of the larger doctrine of maintenance. Now it is a tort only, in earlier times it was a crime and a tort. 
firm of "international probate researchers" and beneficiaries (again long lost cousins) in the Republic of Ireland, was discussed critically by a contributor to the Modern Law Review in 1997. ${ }^{49}$

As well as revealing the operation of dower, then, Sutton $v$ Howells illustrates the extent to which a death in the embryonic colonial township of Waipawa in 1863 could have wide temporal and geographical influence. The connected nature of colonial and metropolitan societies, an argument made strongly in recent "new" imperial history, is amply demonstrated by such instances. ${ }^{50} \mathrm{~A}$ shared legal system, a network of continuing - if fractured - kin relationships, global business operations, all come to light through a single and, at first glance, unremarkable case. Life is always, however, lived in the specific and local. For the residents of Waipawa the discovery of descendants of William Howells at the end of the century was not such good news. The local town library, much sought after and hard worked for through fund raising, voluntary effort and a grant from the local council, had been built on land leased from trustees of the Howells estate. So long had the land lain unused, in public administration, that it came to be regarded as publicly available space - though the lease agreement did make provision for compensation for improvement or removal (neither easily practicable). In 1891 there was considerable anxiety that the Howells' "heiresses" would force the sale of land (through Public Trustee needing to realise assets) in the estate. The Library committee had to work hard to find a solution. ${ }^{51}$ They did so.

\section{JOHN AND HANNAH MCLEAN. GRAY V BEVERLEY, 1866}

The second case through which to see the law of dower in action in colonial New Zealand concerns John and Hannah McLean, runholders living at Kurow Station in the Waitaki Valley in North Otago, in the late 1850s and early 1860s. This case could be termed that of "the dissolute widow". While moral judgements were not supposed to, and did not in fact, cloud the entitlement of a widowed woman to property through dower right, officials charged with administering the estate were clearly coloured by their view of the woman at the centre of this episode.

By the early 1860s, John McLean had established a highly successful run in the Waitaki Valley, running his own sheep and flocks under a lease agreement with one of his neighbours the Studholmes. In 1862 John and Hannah McLean were significant runholders; in their late 30s, they had a family of 6 children, from the eldest, 13-year-old George, down to youngest, Robert, at just 5

49 The judgement set the basis for what could be accepted in such agreements, making them champertous and void if the heir locator undertook to render assistance in recovering the inheritance such as by gathering evidence and financing litigation: Rees v de Bernardy, above n 33; David Capper "The Heir-Locator's Lost Inheritance" (1997) 60 Modern Law Review 286.

50 See for example Tony Ballantyne Orientalism and Race: Aryanism in the British Empire (Palgrave, New York, 2002); Catherine Hall Civilising Subjects: Metropole and Colony in the English Imagination 18301867 (Polity Press, Cambridge, 2002); Tony Ballantyne and Antoinette Burton (eds) Moving Subjects: Gender, Mobility and Intimacy in an Age of Empire (University of Illinois Press, Urbana, 2009).

51 Hawke's Bay Herald (Napier, 30 November 1891) at 3. 
months. ${ }^{52}$ On the Sunday night of 2 March 1862 their lives came to a dramatic crescendo. While Hannah, according to her own account, was in another part of the house putting the children to bed, her husband fell from the chair he had been sitting on in the living room, hitting his head and landing heavily on the floor, leaving him unconscious. David Gray, the station overseer, who was also in the living room that evening, picked up McLean and placed him on a bed. But McLean failed to recover consciousness and died later that evening. By the time Dr Williams had been called and arrived - travelling over 40 miles from the nearest town of Oamaru - his patient was well dead. The local resident magistrate, TW Parker, also travelling from Oamaru, convened an inquest 4 days later, on 6 March, the body then lying in the woolshed adjacent to the homestead. Evidence was taken from several witnesses including Hannah McLean, David Gray and Dr Williams, but the jury of nine men returned an open verdict, concluding "that there were certain marks of violence on the right side of the face but how they were received there is no evidence to show". 53

By the time Parker returned to Oamaru rumours concerning McLean's death led him to make further enquiries. On 10 March, in Oamaru, he took further evidence from a witness by name of Margaret Bell. Bell had been living at Kurow Station earlier in the year while her husband worked as a shearer. Her evidence was attached as an Addendum to the inquest file. On 22 March the Otago Witness ran an article drawing attention to McLean's death "under extraordinary circumstances", publishing the complete file of inquest evidence. ${ }^{54}$ Suggestions made about the evidence raised suspicions about the nature of injuries sustained by McLean, namely, that these were not consistent with falling off a chair - even if seriously inebriated - and that Hannah McLean and/or David Gray were dissembling, or worse, over the events that took place in the station living room that night.

Suspicions had already led Parker to act. On 12 March, the same day as he registered John McLean's death, he forwarded the full inquest papers to Robert Chapman, Registrar at the Supreme Court in Dunedin, who in turn forwarded the file and Parker's letter to the Provincial Solicitor. In a postscript to his letter Parker defended the fact that there had been only nine jurors at the inquest,

52 Robert Pinney Early Northern Otago Runs (Auckland, Collins, 1981) at 89-90, provides brief details on McLean at Kurow. Thanks to Jim McAloon for this reference. McLean was known as "little McLean" to distinguish him from namesake at Morven Hills. The vacant Kurow run was taken up by McLean for 14 years from 22 December 1856. He had been a shepherd, "probably on Maerewhenua or Ben Lomond": (Pinney Early Northern Otago Runs, ibid at 89). Pinney states that the aspersions against Mrs Mclean stuck and that she became a destitute in Oamaru. He also notes that the station was sold for McLean's intestate estate to Douglas and Alderson for $£ 15,000$ with 10,000 sheep, "but it took a long while to disentangle McLean's affairs" (at 89). By 1866 Kurow was transferred from Douglas and Alderson to New Zealand and Australian Land Company.

53 The wording of the verdict was as follows: "was found to have died from an injured state of the brain and of the blood vessels of the head, and that there were certain marks of violence on the right side of the face but how they were received there is no evidence to show.", Coroner's inquest file John McLean, ANZ, Wellington, J46, box 4 .

54 Otago Witness (Dunedin, 22 March 1862) at 2. 
explaining that in "some places remote from a Town it is impossible to get the requisite number". 55 A detective was subsequently detailed to investigate the information provided. In April Hannah McLean, John's widow, was charged with wilful murder of her husband.

The Otago Witness proudly claimed responsibility for championing the pursuit of justice. "Charges of ill-treating her husband who was old and helpless, were also laid against her," the paper noted. ${ }^{56}$ In fact, the death certificate gave John MacLean's age as 37 years. ${ }^{57}$ Nevertheless, public opinion was not on her side. Both reports carried by the Otago Witness noted that he was "an old and well-known settler" in the province, someone who was "steady and industrious". It also observed that his "property is very large; he had two stations, and he cannot have left behind him less than $£ 10,000 " .58$ The final comment in the report of Hannah McLean's arrest for murder noted that besides "the question of the murder, great difficulty is likely to arise concerning the disposal of the property, which is of considerable amount". ${ }^{59}$ In this the paper was certainly prescient.

In the event, insufficient evidence was marshalled in support of the accusations and Hannah was subsequently discharged. With the murder charge out of the way Hannah McLean went ahead with an application to obtain Letters of Administration over the estate of her husband John McLean. Chapman, the Registrar, had already made it clear in his correspondence with the Provincial Solicitor that he would oppose such an application. Judge C W Richmond sitting in the Dunedin Supreme Court, refused Hannah's application. ${ }^{60}$

Like William Howells, John McLean died intestate. Magistrate Parker of Oamaru, in a private letter to Chapman, noted that McLean "left considerable property ... a good Station on the Waitaki, $\&$ another on the Manitoto Plains and they and the sheep must be worth I should suppose at the least ten thousand pounds \& perhaps much more". ${ }^{61}$ Robert Chapman, as Registrar and official administrator of intestate estates, swore an affidavit setting out circumstances of McLean's death and related matters on 30 May and was subsequently granted administration of the estate on 6 June 1862. It is clear he believed Hannah guilty of adultery, and gross misdeeds, even if not actually

55 TW Parker to Robert Chapman (12 March 1862), DAAC/9074/280 A1778, ANZ (Dunedin).

56 Otago Witness (Dunedin, 26 April 1862) at 7.

57 Certified copy of entry in register book of deaths, Oamaru, 1863/8, ANZ (Dunedin), DAAC/D140/21.

58 Otago Witness (Dunedin, 22 March 1862).

59 Otago Witness (Dunedin, 26 April 1862).

60 Keith Sinclair "Richmond, Christopher William 1821-1895" (2007) Dictionary of New Zealand Biography <www.dnzb.govt.nz> [DNZB].

61 TW Parker to Robert Chapman (12 March 1862) DAAC/9074/280 A1778, ANZ (Dunedin). 
guilty of murder. The youngest child was believed to be that of Hannah and Gray rather than Hannah and John McLean. The affidavit includes the following statements: ${ }^{62}$

I Robert Chapman of Dunedin Official Administrator of the Intestate Estates Swear

1. That I am informed and verily believe that the said deceased John Maclean died in a state of drunkenness which drunkenness was habitually encouraged by Hannah Maclean his wife.

2. That I am informed and verily believe that marks of violence existed on the body of the deceased at the time of his death and at the inquest on the body of the deceased the jury gave an open verdict as to the cause of death.

3. That I am informed and verily believe that the said Hannah Maclean has been seen to beat and ill use the said deceased.

4. That the facts above mentioned appear in the depositions upon the inquest on the body of the deceased which depositions are herewith produced, marked A and as herein referred to.

5. That I am further informed and verily believe that the said Hannah Maclean was at the time of the death of said deceased and previously thereto living in a state of adultery with one David Gray.

The drama and scandal of the McLean case did not finish here. Managing the McLean estate became a major preoccupation for Chapman over the next four or more years, in addition to his other duties as Registrar at the Dunedin Court. Surviving files also suggest that its administration provided considerable business for the Dunedin legal fraternity. In the first instance Chapman acted to install his own manager at the station to protect the estate's major asset. William McCulloch was sent to Kurow on the Waitaki in July to undertake this job. Immediately he found himself in conflict with widow Hannah. Although he had been instructed to "soft peddle" he found it hard. ${ }^{63}$ By August their relationship was one of hostility and conflict. McCulloch reported to Chapman in early August a recent affray whereby Mrs McLean had taken goods from the station store and demanded others when the store was locked - flour, rice, soap, bottles of gin. McCulloch had refused the gin, and doled out meagre portions of the rest. Making matters worse was the presence on the station of

62 John McLean Estate, DAAC/9074/280 A1778 ANZ (Dunedin).

63 Chapman to McCulloch (August 1862) DAAC/D140/21, ANZ (Dunedin). 
David Gray. Gray was, from an early stage, referred to in correspondence between Parker, Chapman and McCulloch as "that scoundrel". ${ }^{64}$ It was not just McCulloch who got offside with Hannah. Resident magistrate Parker continued to consider her character black. In early September he wrote to Chapman with the following: ${ }^{65}$

My dear Sir,

That detestable woman seems likely to be a thorn in the side of more than her unfortunate husband but although she was the cause of his death in a moral sense, I doubt if she will be as successful in killing the official administrator.

It would a be a great blessing for the children if she were dead - or even transported for ten years would be better than nothing. I would gladly lend her a helping hand.

At the same time as McCulloch was writing in boiling frustration to Chapman about his situation, Hannah McLean had gone to Dunedin with Gray where they were married on 12 August 1862 at the Episcopal Church, a bare five months after her first husband's death. Hannah and David Gray returned to the station, to McCulloch's deep chagrin. He finally applied to Parker in Oamaru and through him to Chapman for a warrant for Hannah's forcible removal. In the event, the warrant was not used, but the scene was unpleasant. McCulloch reported to Chapman that Hannah left taking with her several horses plus a pony ridden by her eldest son George. He was not sure if this was legitimate removal of assets of the estate. Clearly there was a question of whether she was entitled to such valuable assets.

Hannah and her children went to live in Oamaru, but later in year Hannah returned again to the station to collect two cows saying she needed them to provide milk for her children. McCulloch reported this disapprovingly. The widow's continuing depradations on the estate were a matter of concern. ${ }^{66}$ By the end of 1862 Chapman was deep in deliberations as to whether it was best to sell the property before or after summer shearing and endeavouring to find fair minded valuers. Getting reliable advice was not always easy, and at a time when Otago was "mad" with gold fever, even less so. ${ }^{67}$ Much to-ing and fro-ing continued on matters relating to the administration of John McLean's sizeable estate.

Meanwhile, things did not go well for Hannah. Her second husband, Gray, anticipating the wealth he might get his hands on via his wife's and her children's inheritance from the estate, built a lavish house in Oamaru, ostensibly for the family. He also embarked on other sizeable expenditure.

64 Ibid.

65 TW Parker to Robert Chapman (7 September 1862) DAAC/D140/21, ANZ (Dunedin).

66 William McCulloch to Chapman (15 November 1862) DAAC/D140/21, ANZ (Dunedin).

67 Erik Olssen History of Otago (McIndoe, Dunedin, 1984). 
It was all rather too grand and too anticipatory. By the summer of 1862-63 he was being pursued for debt. His creditors, principally the Dunedin firm of James Rattray and James Brown moved decisively. By early 1863 the only way out from insolvency was for Gray to sign over the whole of his estate to their firm. Rattray and Brown proved persistent and resilient claimants. A further tragedy hit the McLean family when the eldest of Hannah and John's children, George, aged 14, died of "disease of the heart" on 9 April 1863. An additional strand in the administration of his father John's estate now involved the trustees of George McLean's interest. ${ }^{68}$

The estate realised around $£ 23,000$, with $£ 15,000$ coming from the sale of the Kurow run. ${ }^{69}$ Hannah's entitlement to a third of the property, and her children to two-thirds, was upheld. Hannah took some steps to protect her share of the distribution. On the same day as she married Gray, 12 August 1862, she made out a marriage settlement in which she set aside half of her third portion from the estate for her use (under trust), while the other half became the property she took into her second marriage - essentially under David Gray's control. Following his insolvency, that portion went to his creditors. In 1866, as Hannah Gray, she was still litigating her portion of her first husband's estate through the marriage settlement in the case Gray v Beverley. Beverley was Arthur Beverley, Dunedin solicitor, trustee under the marriage settlement. It was heard in the Dunedin Supreme Court by Judge Chapman. It was this case, over marriage settlement, that was picked up by the Lost Cases' researchers, providing the first clue in a trail which led back into what turned out to be a complicated and sensational set of events. ${ }^{70}$ The issue of the trust in marriage settlement opened up a much bigger can of worms, and appears to raise question as to whether Hannah has an absolute or life interest in her portion of the estate. However, the entry in the Judge's notebook is fragmentary, so the story remains incomplete.

Where does this tangled, messy and tragic tale of Hannah and John McLean (and lesser protagonists) lead us in a study of dower right and its significance in nineteenth-century New Zealand? Most of the copious case materials revolve around the administration of estate in which dower is only one small element. But it does illustrate the circumstances in which dower operated, and in which property, family relationships, colonial circumstances are all entangled. Hannah, reportedly, ended up destitute in Oamaru. ${ }^{71}$

While charitable organisations were established as early as the 1840 s in some parts of the country, the provision of assistance to those in need was fragmentary, uneven and sporadic in most

68 George McLean Estate, DAAC/9074/254 A1021, ANZ (Dunedin). Death certificate George McLean, Register of Births, Deaths and Marriages, Department of Internal Affairs, registration number 1863002073.

69 (29 June 1866) New Zealand Government Gazette at 273; the estate was valued at £23,154.0.21/2: DAAC/D140/21, ANZ (Dunedin).

70 Gray v Beverley, above n 2.

71 Pinney Early North Otago Runs, above n 52, citing newspapers, at 89. 
places prior to the inauguration of a national system of charitable aid in the 1880s. New Zealand, according to some accounts, was designed as "a world without welfare", ease of property ownership and economic opportunity rendering want a thing of the "old world". ${ }^{72}$ Nonetheless, women whose husbands died, deserted, or otherwise proved unreliable providers, presented recurring cases of need. The Otago Benevolent Institution was established in 1862 and a refuge largely for pregnant single women in Christchurch a few years later. But such establishments generally drew a sharp line between "deserving" and "undeserving" cases. Hannah McLean's reputation would not have served her well in making a plea for assistance at these doors. The plight of a destitute woman in small and often censorious colonial communities could be harsh. ${ }^{73}$

A third case which is mentioned only very briefly, as the record is as yet extemely scanty, further illustrates the exercise and potential contest around dower right in nineteenth-century New Zealand. Clarke \& wife v Laurie was heard by Justice Gillies in the Auckland Supreme Court between July 1874 - Dec 1875. The plaintiff, Clarke, was a sailor. His wife, whose name, alas, is not noted, was formerly the widow of one James Grainger. Clarke went to the court applying for a "decree for dower" in property now owned by James Laurie, the defendant. The property in question was claimed to have been formerly owned by Grainger. After a direction to investigate, Gillies J granted the decree. The proceedings began in December 1874, and concluded, following investigations, in July $1875 .{ }^{74}$

\section{DOWER IN THE SETTLER PARLIAMENT}

Turning to consider the New Zealand legislature's interest in dower takes us initially to the 1854 Dower Act, one of the earliest measures to be debated in the embryonic local assembly in its first sitting following the 1852 Constitution. Issues of marriage and property proved central to the establishment of colonial governance. The Marriage Ordinances of 1842 and 1851, and Act of 1856, together with the Dower Act 1854, were important foundations to the success of a settler colony. ${ }^{75}$ Dower returned to the assembly's attention through attempts in the early 1870 s to reshape "real estate descent" law in measures defining inheritance and property. The period from the mid 1860s

72 David Thomson A World Without Welfare: New Zealand's Colonial Experiment (Auckland University Press, Bridget Williams Books, Auckland, 1998) [A World Without Welfare].

73 Margaret Tennant The Fabric of Welfare. VoluntaryOrganisations, Government and Welfare in New Zealand, 1840-2005 (Bridget Williams Books, Wellington, 2007); Margaret Tennant, Paupers and Providers: Charitable Aid in New Zealand (Allen \& Unwin, Historical Branch Internal Affairs, Wellington, 1989); Margaret Tennant "Brazen-Faced Beggars of the Female Sex: Women and the Charitable Aid System 1880-1920" in Barbara Brookes, Charlotte Macdonald and Margaret Tennant (eds) Women in History: Essays on European Women in New Zealand (Allen \& Unwin, Wellington, 1986) 35.

74 Clarke \& wife v Laurie, above n 3.

75 Marriage Ordinance 18425 Vic No 11; Marriage Amendment Ordinance 185115 Vic No 7; Marriage Amendment Act 185619 \& 20 Vic No 12; Dower Act 185418 Vic No 3. 
through to end of 1870s stands out as one of considerable legislative activity in regard to property, land and estate administration. This legislation was part of wider moves to establish property right in land in simple, transferable, unencumbered form as swiftly as possible. It came into being in the context of colonial wars fought in Taranaki, Waikato and elsewhere in the North Island, not only over land but over the assertion of a single authority exercised through law, politics and also by force.

In the brief two-clause 1854 Dower Act New Zealand's law endorsed and extended provisions in the Imperial Act of 1833. Instead of distinguishing between those married before or after the Act's commencement on 1 January 1834, the New Zealand measure made all widows subject to the 1833 provision. ${ }^{76}$ The preamble reiterated the intent of the original legislation in removing the obstacle of dower from transactions in land. As it spelled out, "the rights of women ... to dower out of the lands and tenements of which their husbands may at any time have been seized during their coverture occasions considerable expense inconvenience and delay in the alienation of real estate". The rights of women to dower are clearly set against the ease of purchase and sale of real property.

New Zealand legislators' awareness of dower in the early assembly of 1854 seems most likely to have been prompted by recent debate of the issue in New South Wales. There is no evidence of a local case prompting action. In October 1850 a Select Committee of the New South Wales parliament was convened to consider "Laws of Real Property and of Dower Bills". ${ }^{77}$ Essentially, it recommended further reduction of dower right beyond the already circumscribed limits of the 1833 Imperial Act. AR Buck and Nancy Wright draw attention to the competing arguments put by lawyers to the Select Committee - one view being that widows who were not resident in the colony had no entitlement to dower over property in the colony, and the other that upheld dower right wherever the widow might be resident and wherever the property might be located. The common law property right was a right regardless of residence or location argued those of the second persuasion. Arguments that supported further curtailment of dower right won the day. New South Wales, like other colonies, was keen to free up land title and moved to limit dower. ${ }^{78}$

The major debate about dower right in New Zealand occurred in the early 1870 s as part of wider debates around the reform of inheritance and real estate provision, through a series of failed Bills, and finally in successful Acts. Dower was not so much at the centre of these measures but was caught up in the sweep of what they encompassed in changing the status of real property (land) and thereby bolstering individual property in land. The Real Estate Descent Act 1874 (NZ), was the first

76 Dower Act 185418 Vic No 3, s 1

77 Report from the Select Committee on the Laws of Real Property and of Dower Bills (Government Printing Office, Sydney, 1850).

78 Buck and Wright "The Law of Dower", above n 7; see also Golder and Kirkby "Land, Conveyancing Reform", above n 7. 
major step.It applied only to intestate cases, and only to men. Section 2 specified: "This Act shall apply to every male person dying after this Act comes into operation, leaving him surviving a wife or child or children or any lineal descendant." The measure thus recognised a difference at law of men and women. Section 3 provided that all (and any) real property, in effect all land, left in such estates would "pass to and become vested in" the personal representative of the person dying (usually an executor or person acting in such a capacity through letters of administration) who was then given the power to dispose and distribute such property (and proceeds) by the same rules as if they were personal property. ${ }^{79}$

In two very important ways, therefore, the 1874 Act altered the status of real property (land) and in so doing shaped distinctively colonial patterns of inheritance, wealth, and property ownership. In changing the status of real property so that it passed to the executor or administrator of the estate, rather than directly to an heir it removed its special status, effectively getting rid of primogeniture. Secondly, the Act put real property (land) and personal property on the same footing, making both easily disposed of. The administrator was instructed to sell property "with all convenient speed" (s 6). In this regard New Zealand followed the wider settler colonial tendency to diminish the distinction between realty and personality. ${ }^{80}$ In making these provisions, the 1874 Act also removed the basis for claims of dower. Garrow describes the 1874 Act as rendering "the law as to dower"... "obsolete" for women whose husbands died after 1 October 1875 when the 1874 Real Estate Descent Act came into force. ${ }^{81}$ The final formal abolition of dower in New Zealand law came in 1905 when the 1833 Act was repealed as part of the Property Law Act. ${ }^{82}$

The 1874 Real Estate Descent Act, was, in many ways a very significant step in marking the departure of a colonial law from its English parent. It did not have an easy path through the New Zealand Parliament. Indeed, the passage of the 1874 legislation was the end point of a series of failed Bills. An Intestate Estates Bill was debated and defeated in 1871. A Real Estate Bill and Real Estate Succession Bill were debated but did not proceed in 1872. Questions were asked in the house as to the fate of a Bill on the subject in $1873 .{ }^{83}$ A slightly earlier attempt to consolidate and amend

79 Real Estate Descent Act 1874, s 3: "All land in New Zealand of which any person to whom this Act applies shall die seized or possessed as owner ... shall, with all powers privileges and rights of action attaching or relating thereto, go and pass to and become vested in the personal representative of the person so dying ... and such personal representative shall hold the said land and the unapplied proceeds thereof for division or distribution in like manner as is now the case with chattel real property, ... and [distribute and dispose of it] in like manner as other personal assets".

80 Philip Girard and Jim Phillips "Rethinking 'the Nation' in National Legal History: A Canadian Perspective" Law and History Review, forthcoming. Draft kindly advanced to author prior to publication.

81 Garrow's Law of Real Property, above n 9, at 141, note g.

82 Property Law Act 1905, s 121. Dower right was finally abolished from English law by the Law of Property Act 1925 (UK).

83 (20 Aug 1873) 14 NZPD 544b. 
the laws relating to real and personal property had failed in $1868 .^{84}$ There may have been other attempts also; the trail of failed legislation is much less fulsome than that of successful legislation.

One feature of all the failed Bills, which contain the core provisions of putting real and personal property on the same basis, and directing that they pass to an executor or administrator for distribution rather than real property passing direct to heir-at-law, is that none of them apply only to men (as did the final one). Two of them contained clauses which preserved dower right. The 1871 Intestate Bill, for example, directed that "all lands and hereditaments in New Zealand of which any person shall die seized or possessed as owner ... shall subject to such rights of dower and rights as tenant by the courtesy of England as any person shall have therein ... shall pass to and become vested in the personal representative of the person dying ... etc [and be disposed of on same basis as personal assets]". ${ }^{85}$

Throughout the debates on these measures speakers emphasised a theme of differences between colonial and "Old Country" practice, especially when supporting the proposed changes. They drew attention to such things as wider land holding, as many people in the colony holding small parcels of land; a lower resistance to frequent exchange of land; a more common habit for people with land to die intestate; and, most of all, the observation that all members of family contributed to improvement of land in the colony and thus could have a reasonable expectation that they would benefit from a share in it. Both opponents and supporters asserted the absolute right of a man to make a will and dispose of real property as he chose, ie the defining freedom to will. An Englishman's right to will being upheld as a symbol of national, as well as legal, culture. The difference was in how each side regarded the changes as altering this freedom.

In introducing the Intestate Estates Bill in September 1871, for example, Bunny (Member for Wairarapa) explained that under the present law, a person dying without a will, owning real estate (land) meant that the land would go to his eldest son while other members of the family would get nothing. The Bill simply sought to make land divisable amongst rightful heirs as was personal property. "The Bill did not interfere with the power of any persons to leave their property by will in whatever way they thought fit", he reassured his colleagues. But the "House would no doubt agree with him that, in a country like New Zealand, where there were no old associations of property and descent from generation to generation, and where in many cases landed property was not acquired, as in the old country, by the exertions of the father or husband, but as much or more by the exertions of the wives and children of the family, that, under those circumstances, it was quite fair in case a person died without having made arrangement by will as to how his property was to be distributed, the law should step in and prevent it all from being taken by the eldest son, who probably had very

84 Property Law Consolidation, An Act to Simplify Consolidate and Amend the Laws Relating to Real and Personal Property, 1868, "Bills Rejected 1868-70", Parliamentary Library.

85 Intestate Estates, An Act to Alter the Succession to Real Estate in Cases of Intestacy, 1871, "Bills Rejected 1871-72", Parliamentary Library. 
little to do with the accumulation of property." The Bill was adapted to the Colony, and in framing it they had not taken provisions from English or other foreign Acts. ${ }^{86}$

Richardson (Member for Nelson Suburbs), speaking against the Bill said he had seen no evidence of families being deprived of property as had been suggested, and that they all knew that people "who immigrated to New Zealand, expected to find amongst their own countrymen a similar state of law as that which existed in England ... . He thought the English law had worked well for a number of years - indeed for generations - and he considered they should not alter it". ${ }^{87} \mathrm{Mr}$ Thomson, supporting the Bill, strongly endorsed the principle behind it, declaring that "there was no valid reason why the law of primogeniture should be the law of this country". ${ }^{88}$

John Hall, a Canterbury representative and later premier and supporter of women's suffrage, ${ }^{89}$ introduced a new measure, the Real Estate Bill, in July 1872. Waterhouse, speaking in support, put the case for the need for such a measure. He said: "It was impossible to mix with lawyers without hearing of continual cases of hardship arising from the operation of the existing law on the subject." 90 Sewell, speaking to the contrary, detected in his colleagues, not a measure to remedy injustice amongst families, but a measure which in his view had potential "for altering the whole character of real property, for altering the whole fundamental law of the country as applicable to every species of real estate ... that the Bill proposed to alter in point of fact the relations of husband and wife, and to divert the whole order of succession of property", and he would point out very serious consequences of the Bill. ${ }^{91}$

A few days later Sewell expanded his argument against the measure, explaining that his opposition was not to its attack on primogeniture; that, he acknowledged, was part of a feudal past that was no longer relevant. But he was reluctant to concede the view that "land is now to be regarded as an article of commerce. He was not prepared to say that it is to be altogether so regarded, because he conceived that the tenure, possession, and distribution of land formed the material basis of the constitution of our social system ... Still, he admitted that to a great extent his honourable friend was right in saying that our modern and especially our colonial view was to regard real estate as an article of commerce." 92 This was a critical point. A strong opponent of the

86 (13 September 1871) 10 NZPD 411-412 See also Gisborne's question about how the proposed Bill would affect entitlements of married women and Bunny's reply.

87 (13 September 1871) 10 NZPD 412a.

88 (13 September 1871) 10 NZPD 412a.

89 WJ Gardner "Hall, John, 1824-1907" (2007) DNZB, above n 60.

90 (24 July 1872) 12 NZPD 53a.

91 (24 July 1872) 12 NZPD 53b.

92 (30 July 1872) 12 NZPD 147b 
Bill, Colonel Whitmore, objected to the Bill "root and branch" because it treated land as no more than article of commerce. It was to the law of primogeniture, he declaimed, that "we owed the greatness of our race" and to protect it "we must prevent land becoming in this country a mere article of commerce". ${ }^{93}$ Stokes (Legislative Councillor), also opposing the Bill, believed it was a measure akin to a trojan horse - "instead of being called a Real Estate Descent Bill, it should be called a Bill to abolish the Laws affecting Real Property. That really appeared to be the main object of the Bill," and on that basis he was adamantly opposed. ${ }^{94}$

In 1872 the opponents were in the majority. By 1874 when Waterhouse, Hall, Bunny and supporters of the measure reintroduced a new Bill, this time the Real Estate Descent Bill, the climate was more favourable. The idea had lost some of its novelty, and many objections were overruled. Introducing the second reading Waterhouse attempted to persuade his colleagues of its virtues: "As honorable members were aware, real property was much more generally diffused in this and the adjoining colonies than in the mother country. In the mother country almost every person coming into or having possession of real property, was either acquainted with the laws regulating its descent, or took care to make himself thus acquainted. Here however they had a very large class who were in utter ignorance of the laws affecting the descent of real estate, and through this ignorance frequent injustice was wrought." He went on to note that there was in New Zealand, "a decided objection to making a will, founded upon something like a superstitious feeling of abhorrence to that proceeding". He mentioned a case he knew of in which the man in question was the owner of a large property, was aware of the nature of the law and desirous to do justice to his family. He had a will prepared "but with that superstitious feeling of aversion to signing a will, he did not execute it, but systematically carried it about on his person, so that if he were taken suddenly ill he might give legal effect to what had always been his intention. Unfortunately, however, he fell from his horse one day, and was killed, leaving the will in his pocket unexecuted". 95

Parliament in 1874 was more disposed to Waterhouse's view. It passed the final Bill - applying only to male persons, and intestates - to bring in the 1874 Act. In 1879 provisions of the 1874 measure were extended in the Administration Act. This legislation retained all provisions of 1874 Act in regard to intestacy, but then extended the assimilation of real and personal property to testate wills, and made innovative provision for illegitimate heirs. Essentially, the provisions of the Act upheld the rights of testators to distribute property as they directed by will; if not then real property was to descend as if it was personal property. In general the 1879 Administration Act was a broadening of the 1874 measure.

\footnotetext{
93 (30 July 1872) 12 NZPD $150 b$.

94 (30 July 1872) 12 NZPD 152a.

95 (15 July 1874) 16 NZPD 116a.
} 
The significance of both the 1874 and 1879 Acts is highlighted in their status as "reserved" Acts - that is to say, they departed from English law to such an extent that the Governor did not have the power to pass or approve them but referred them back to England for final assent. This gives an indication of the significant departure in principle from English legal practice they represented. They are part of the long history of "repugnant" or reserved Acts discussed recently by John E Martin. ${ }^{96}$ In fact the 1879 legislation was an amended form of an 1878 Act the Crown had declared "repugnant". An allusion to the divergence of New Zealand from British law in relation to inheritance of land was made in Rees $v$ de Bernardy.

Unlike much of Canada where agrarian ideals, and acknowledgement of the family labour involved in establishing farms led to an elaboration of dower, New Zealand legislators did not pursue that avenue. Instead, they showed themselves concerned with married women whose husbands failed to provide by passing married women's property protection legislation in 1860, 1870 and 1884. These were measures that stemmed from pragmatism rather than progressive principle. ${ }^{97}$ More generally, New Zealand politicians looked to the demographic, social and economic growth of the colony to provide for material welfare, and in particular for women's livelihood. In a situation where women were in demand as wives, mothers and domestic workers (paid and unpaid), where marriage rates were high, and reproduction economically and socially valued, there was little incentive for male legislators to provide for women outside marriage. Indeed, they were at this very time, through the 1860s in provincial assemblies, and in the 1870s through the central government-initiated "Vogel" scheme, voting substantial sums to support subsidised immigration directed importantly to encouraging more women to settle in the colony to support the growth of household economies. Protecting dower right for widows was not a priority. ${ }^{98}$

\section{CONCLUSION}

An initial exploration of dower in New Zealand reveals a small number of cases in which widows' claims came to be part of the administration of estates, and a limited, but significant, concern with dower rights in the colonial legislature. In keeping with the pattern in the Australian colonies, and across much of the British common law world, dower rights were in decline through the nineteenth century. New Zealand's dower history confirms the comparative pattern depicted by Buck and Wright for New South Wales in seeing the demise of dower rights largely preceding the advent of married women's property rights. The opposite sequence prevailed in the common law

96 John E Martin "Refusal of Assent - A Hidden Element of Constitutional History in New Zealand" (2010) 41 VUWLR 51.

97 Bradbury "From Civil Death", above n 11.

98 Charlotte Macdonald A Woman of Good Character. Single Women as Immigrant Settlers in Nineteenthcentury New Zealand (Allen \& Unwin/Historical Branch, Wellington, 1990); Rollo Arnold The Furthest Promised Land: English Villagers, New Zealand Immigrants of the 1870s (Victoria University Press, Wellington, 1981) [Furthest Promised Land]. 
regions of the United States. ${ }^{99}$ The Married Women's Property Act of 1884 and the bolder Testators' Family Maintenance Act of 1900 went some distance to overcoming the legal disabilities faced by women within marriage. These were important legal rights to set alongside the political right to vote won famously in 1893 and the subject of far greater contemporary agitation and historical attention. The history of dower's demise in colonial New Zealand was driven not so much by prominent or troublesome cases as by the strong imperative within the European settler society for a free market in land, and land as the primary property right. The encumbering claim of the "widow's third" on land title was anathema in such a context. Dower rights, thus, form part of the formation of a settler community in which male land ownership was paramount and in which a later active women's movement sought to impose some limits on husbands. The story of dower is inseparable from the larger history of settlement in which European family colonisation and democratised land ownership was built on dispossession and political marginalisation of the indigenous Maori inhabitants.

While the women in whose names dower right was claimed, and at times contested, are rarely the authors of documents comprising the legal archive, the record is an extraordinarily rich lode into the depths of nineteenth-century life. The messy, uncertain world of daily life visible in transactions over the bar, in the woolshed, around the dining table, beneath the eiderdown, and at the race track, emerge vividly in evidence given before inquests, in affidavits laid before courts, in correspondence between officials and in the inventories of possessions laying bare the material fabric with which people earned livelihoods, raised families and negotiated love and loathing, good times and bad. In dealing with crises - death, marriage, property transactions, serious conflict - the operation of the law reached into lives, families and communities to a greater extent and in a less varnished or abstract way than many other sources admit. To historians such a record is invaluable. Predicaments faced by women as widows are especially to the fore in dower cases. While there is no single story to be told, wealth and family circumstances varying widely, the situations of Susan Howells, the later beneficiaries of the Howells estate, the elderly Margaret Walters and Jane Yorke, the unfortunate Hannah McLean and the glimpsed Mrs Laurie provide fresh perspectives from which to view the lives of nineteenth-century women, and in particular the means by which women forged a material basis for their lives when their marriages came to an end. The position of men and the contingent nature of masculinity is also illuminated through the legal record. As lawmakers their debates in parliament reveal struggles over what was considered consistent or desirable in the kind of British colony New Zealand was becoming; a struggle in which political representatives of this era typically had interests as well as ideas. In serving as law enforcers, judges, court officials such as registrars; as jurors, magistrates, coroners, lawyers and as legal subjects in the shape of property owners and testators, they were all acting in various forms of authority and order deriving from structures and practice of something understood as "the law". These were roles and a stage in which men played most of the parts. Again, there is no single story. Alongside Judge C. W. Richmond's

99 Buck and Wright "The Law of Dower", above n 7. 
aesthetic appearance and high intellect ${ }^{100}$ are the marks left by John Jamison and James Norton on an official inquest verdict. They were two of the nine men who comprised the inquest jury on the body of runholder John McLean. ${ }^{101}$ What did these unlettered men make of the process in which they were summoned to adjudge the cause of their boss' death, a death from drink in the homestead parlour where their overseer and Mrs McLean were also present?

Further research is needed to fill out this initial and sketchy portrait of dower in New Zealand, and to place it more firmly within the broader comparative perspective. A greater survey of cases heard before the Supreme Court, or simply dealt with in lawyers' offices, would expand the view of how dower right actually operated in New Zealand. The expanding coverage of Papers Past ${ }^{102}$ will assist such work, as will an extension of the invaluable Lost Cases' project. Just as we know relatively little about the use and nature of marriage settlements in New Zealand (except that many existed), ${ }^{103}$ we know relatively little about claims to the "widow's third". A better picture of marriage law in practice (including dower), as well as statute, would enrich the growing understanding of marriage as part of the making of colonial New Zealand and the wider imperial world. Wanhalla, Bradbury, Porter and Macdonald, Brown and others have expanded the picture but there remains much yet unknown. ${ }^{104}$ There is more to be investigated of the debates around land ownership, property rights, gender and entitlement of Maori and settler interests in law in the developing New Zealand colonial jurisdiction. Dower adds another dimension to the centrality of marriage and land ownership in the building of a settler society - whether conceptualised as a successful part of a remarkable "Anglo world" (Belich), a "world without welfare" (Thomson), a

100 Keith Sinclair "Richmond, Christopher William 1821-1895" (2007) DNZB, above n 60; Frances Porter Born to New Zealand: A Biography of Jane Maria Atkinson (Allen \& Unwin/Port Nicholson Press, Wellington, 1989).

101 Coroner's inquest file John McLean, ANZ, Wellington, J46 Box 4.

102 The National Library of New Zealand's Papers Past database is available at <www.paperspast.natlib.govt.nz>.

103 Bradbury "From Civil Death", above n 11, at 47.

104 Wanhalla In/visible sight, above n 18; Bradbury "Civil Death", above n 11; Porter and Macdonald "My Hand Will Write, above n 4; Jessica Brown "Trouble in Paradise: Marital Conflict and Desertion in New Zealand 1846-1867" (BA (Hons) Research essay, Victoria University of Wellington, 2010). 
yeoman's dream (Wakefield and modified by Arnold), a "man's country" (Phillips), an ideal society under siege (Fairburn) or as a place in which women gained early political gains as reward for their work as "colonial helpmeets" (Dalziel, and see forthcoming collection as critique). ${ }^{105}$

105 James Belich Replenishing the Earth (Oxford University Press, Oxford, 2009); Thomson World Without Welfare, above n 72; Arnold Furthest Promised Land, above n 98; Philip Temple A Sort of Conscience: The Wakefields (Auckland University Press, Auckland, 2002); Jock Phillips Man's Country? The Image of the Pakeha Male (rev ed, Penguin, Auckland, 1996); Fairburn The Ideal Society, above n 30; Raewyn Dalziel "The Colonial Helpmeet: Women's Role and the Cote in Nineteenth-Century New Zealand", Barbara Brookes, Charlotte Macdonald and Margaret Tennant (eds) Women in History (Allen \& Unwin, Wellington, 1986) 55. 